\title{
Analysis of Spatial and Temporal Variation of Land Use/Land Cover and Impacts on Climate in Urban Areas, Sri Lanka with Special Reference to Hambantota Divisional Secretariat Division (2008- 2019)
}

\author{
Edirisooriya K V U I ${ }^{1}$, Senevirathna E M T K ${ }^{2}$, Edirisooriya K V D ${ }^{3}$, Dheerasinghe G W M M K ${ }^{4}$, Dauglas D L P M \\ ${ }^{1,4}$ Department of Oceanography and Marine Geology, University of Ruhuna, Sri Lanka \\ ${ }^{2,3}$ Department of Geography and Environmental Management, Sabaragamuwa University of Sri Lanka \\ ${ }^{5}$ Geological Survey and Mines Bureau, Sri Lanka
}

\begin{abstract}
The changes in air temperature with the land use / land cover (LU/LC) in the certain areas highly affect to the environment and its ecosystem. This study aims to evaluate LU/LC changes and their impacts on climate in Hambantota Divisional Secretariat Division from 2008 to 2019. Both LU/LC cover changes were determined by using supervised classification, particularly maximum likelihood classification and accuracy assessment in Remote Sensing and GIS techniques. Spatial distribution of air temperature is determined by Inverse Distance Weighting (IDW) method by assigning values to unknown points are calculated with a weighted average of the values available at the known points. The results found that the increment of built-up areas $(27.66 \%)$, water bodies $(2.39 \%)$ and agriculture $(0.44 \%)$ and decrement of barren lands $(11.61 \%)$ and forest cover $(\mathbf{1 8 . 8 8 \%})$ having accuracy ranged from 86.7 percent to 83.3 percent with 0.888 to 0.912 Kappa statistics. These changes are further confirmed by the Normalized Different Vegetation Index (NDVI). Moreover, the increment of air temperature is detected during 11 years. This air temperature increment is proportional to the forest cover reduction and the buildup area increment due to vast developments in the area after 2009.
\end{abstract}

Keywords- Land use / land cover, remote sensing, supervised classifications, air temperature, maximum likelihood, climate

\section{INTRODUCTION}

L and use/ Land cover (LU/LC) changes in emerging cities have several negative consequences for both city residents and the environment. Understanding the nature of land change is therefore critical for city development planning. LU/LC changes are two separate terminologies which are often used interchangeably [1]. Land use is the manner in which human beings employ the land and its resources. Examples of land uses include agriculture, urban development, grazing, logging, and mining. In contrast, the land cover describes the physical state of the land surface. Land cover categories include cropland, forests, wetlands, pasture, roads, and urban areas [2]. Land use change is the conversion of a piece of land use by humans, from one purpose to another and land can be converted from forest area to cropland, cropland to grassland or from wild land to human-specific land uses. Formal and informal development projects directly affect land use also. The growth of this area without proper planning led to creating many complex problems for humans, animals, and the environment in the area. These developments are mainly affecting the changes in the vegetation cover in the area.

GIS and remote sensing applications result in various types of geospatial analysis with greater accuracy, and provide a foundation for data analysis, updating, and retrieval. Nowadays, satellite data are very applicable and are useful for detection for the LU/LC changes. With the invention of Remote Sensing (RS) and Geographical Information Systems (GIS) techniques, mapping the LU/LC change in a region has given a useful and detailed way to improve the selection of areas for agricultural, urban, and/or industrial purposes. With the advent of high spatial resolution satellite imagery and more advanced image processing, GIS has led to a shift to more conventional, consistent LU/LC pattern monitoring and modeling. Similarly, remote sensing is widely used in the update of LU/LC changes maps, and those have become one of its main applications.

When recognizing LU/LC for a given area of interest, two common approaches are used to classify each pixel in an image known as supervised and unsupervised classification. In supervised classification, an analyst uses already procured information of an area, or earlier knowledge, to locate specific areas, or training sites, which represent as homogeneous samples of known land use land cover types. Based on the statistics of these training sites, each pixel in an image is then assigned to a user-defined LU/LC type (cropland, grassland, salt affected and waterlogged, etc.) [3]. Unsupervised classification is useful for scenes in which land cover is not well-known or undefined. This classification is supposed to 
automatically categorize all pixels in an input image into land cover classes. Computer algorithms group similar pixels into various spectral classes which the analyst must then identify and combine into information classes [4].

Vegetation coverage is important for the maintenance of land condition and ecosystem balance in the area. Detection of vegetation dense can be used as a tool for monitoring dynamics of the ecosystem [5]. Vegetation density can be evaluated by calculating of natural vegetation index. NDVI is the most common formula to calculate the value of vegetation index and give information related to the primary production of vegetation [6]. The vegetation index (VI) is one of the most useful and widely used indexes for identifying vegetated areas with the use of multispectral remote sensing data. Red and near-infrared band in satellite images (Landsat 8) helps to derive NDVI. NDVI calculation based on red and nearinfrared reflectance received by Landsat which calculated as a ratio difference between measured canopy reflectance in the red and near-infrared bands respectively. Many researchers have reported the utilization of NDVI for vegetation monitoring assessing the vegetation cover, drought monitoring and agricultural drought assessment at the national and global levels. However, while particular forms of vegetation indices, such as NDVI, can track deviations of various plant growth parameters from normal conditions [7]. Vegetation depletion due to high urbanization caused to make detrimental climate changes in the world. Hence, climate change is one of the major environmental issues in both developed and developing world at present. High rates of deforestation, industrialization, usage of heat-trapping gases are some of other the influencing factors in altering the climatic parameters in the world. Depletion of the Ozone layer, sea-level changes, rainfall variation and global warming, drought, flooding, and other climatic variables all reflect changes in climatic parameters. Global warming is the outcome of the different process which increases the air temperature in the earth's surface. Even small increases in average global temperatures can have destructive effects on people, wildlife, and the environment. Climate change studies have become an essential part of understanding and predicting climate change as it exacerbates the effects of natural disasters such as floods, droughts, heavy rainfall, and temperature [8].

In Sri Lanka, Hambantota district has undergone large-scale developments under government and foreign authorities to transform into the largest urban hub. These developments mainly affect to the natural environment especially in the forest cover in the area. This long-term reduction may cause changes in the normal temperature patterns and climate change as well. It is very important to analyze the whether the land cover changes are affect to the climate change of the Hambantota area. However, there are a handful of published studies available about relationship between LU/LC change and its effect for climate change in Hambantota area, Sri Lanka. Therefore, GIS and RS techniques facilitate to study of detailed and accurate land use classification and LU/LC changes as well as its impacts on climate in a particular area and, can predict the changes in past, present and future also. This study discusses the sustainability of those development projects and provides guidance to carry out national level developments with considering proper sustainable plans.

\section{A. Objectives}

The main objective of this study is to explore the spatial and temporal variation of LU/LC changes and their impacts on climatic parameters such as, air temperature in Hambantota divisional secretariat division from 2008 to 2019. In addition to the main objective, the following specific objectives were formulated.

- Identify major land use categories in Hambantota divisional secretariat division 2008 to 2019.

- Assessment of the LU/LC classification of Hambantota divisional secretariat division from 2008 to 2019 using supervised classification in remote sensing and GIS techniques.

- Use the accuracy assessment method for the supervised classification technique to evaluate the accuracy of the LU/LC classification.

- Examination of the spatial and temporal variations of air temperature in Hambantota divisional secretariat division Sri Lanka during the last 10 years.

- Identifying the seasonal changes of air temperature in Hambantota divisional secretariat division, Sri Lanka during the last 10 years.

- Examination the relationship between LU/LC and spatial changes of air temperature in Hambantota divisional secretariat division, Sri Lanka.

\section{B. Study Area}

According to the data given by the department of senses and statistics, Hambantota District covers $1 / 25$ of the total landmass of Sri Lanka, lies between 6.0 to 6.5 north latitude and 80.6 to 81.7 east longitudes. The maximum length of the district is $106 \mathrm{~km}$ while the maximum width is $39 \mathrm{~km}$. The length of the coastal belt is $151 \mathrm{~km}$ and 11.5 square $\mathrm{km}$ are covered by internal reservoirs from the total landmass of the district. This district is bounded by Monaragala, Rathnapura Districts on the north, Matara District on the west and the Indian Ocean and Ampara District is on the south and the Indian Ocean is on the East. The reason to choose the Hambantota district for the study implies that the specific land use/ land cover relationships are represented. From 2009 most of the major development projects were started by the local governments to develop Hambantota area including the construction of a new seaport, international airport, administrative zone, conference hall, international cricket stadium, etc. These projects are said as a part of the government's plan to convert Hambantota district into the second major urban area of Sri Lanka. 


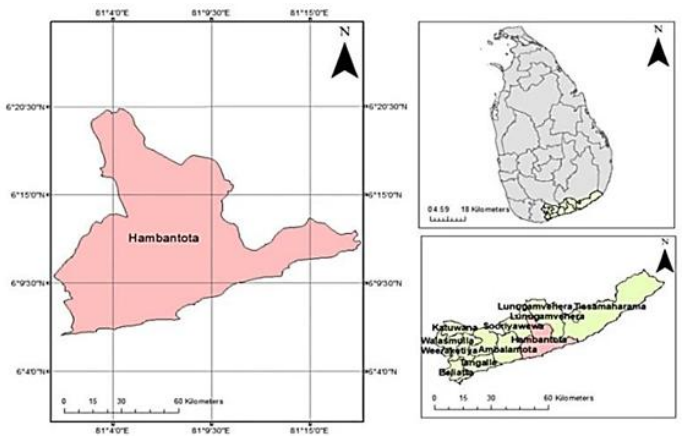

Fig. 1 Study area

\section{METHODOLOGY}

\section{A. Data Used}

The study is entirely based on secondary data which are Landsat $7 \& 8$ data with $30 \mathrm{~m}$ spatial resolution in 2008 and 2019. Those satellite images were taken from United States Geological (USGS) Earth Explorer and as supporting data Google Images were obtained from Google Earth Pro for 2008 and 2019.

Moreover, published and unpublished data on the land use changes related to the particular area used for this study. Climatic change analysis is also based on secondary data (air temperature). Air temperature of the Hambantota district in Sri Lanka was collected from Meteorological Department and NASA. Data was collected for 4 stations in Hambantota district including, Badagiriya Tank, Bundala Lewaya, Maha Lewaya and Mirijjawila. Monthly average air temperature, monthly maximum average air temperature, monthly minimum average air temperature, and annual temperature data have been collected from above-mentioned stations from 2008 to 2019.

\section{B. $\quad$ Method}

The research methodology is described in Fig. 2. This paper comprises three sections:

1. Land use/ Land cover (LULC) classificationSupervised classification (maximum likelihood)

2. NDVI analysis

3. Spatial and temporal distribution of air temperature IDW Method

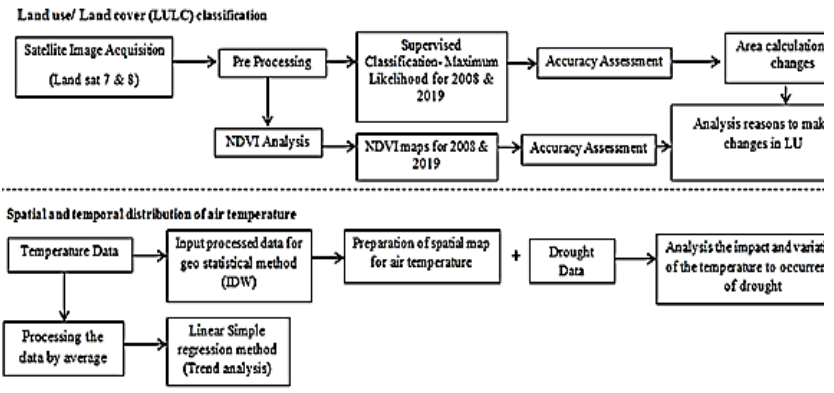

Fig. 2 Methodology of the study

\section{Land Use/Land Cover (LU/LC) classification:}

Image Pre-Processing - The classification process and analysis of the different LU/LC classes were done using Landsat $7 \& 8$ satellite images for 2008 and 2019. The quality of those Landsat satellite images was influenced by cloud cover and atmospheric errors. The image was then processed in ERDAS IMAGINE 2014 software. Bands 3, 2, and 1 are used to combine to make true-color composite images for land use land cover analysis. Then, the study area was extracted by clipping from the prepossessed satellite using ArcGIS 10.5 software.

Land use/ Land cover (LU/LC) Classification- There are various types of methods for analyzing land use/ land cover changes using GIS and remote sensing methods. One such method is image classification. In this research supervised classification method using Maximum Likelihood Classification has been used for the LU/LC maps for the study area as it is a more suitable method because resultant informational classes are tied to specific areas of known identity and high classification errors are often detected. Supervised classification using Maximum Likelihood Classification is the preferred method of image classification, because it is very effective and accurate in classifying satellite images as well as the probability of classification is calculated for each class rather than calculation is based on distance. This method comprises the training stage, classification stage, and accuracy assessment method. However, the user processing the image needs to have a priori knowledge of where the classes of interest (land cover types) are located, or be able to identify them directly from the imagery and classified the image by computer based on the training sites which can identified. According to the land use pattern for certain study area, five training sites were generated as shown in Table 1. Generally, the training samples are taken into a vector layer that is digitized over the raster scene. By identifying patterns, the computer system uses these training samples and instructed to identify pixels with similar characteristics [10] in the entire image, if the classification is accurate; the resulting classes represent the categories within the data that were originally identified. If the pixel is not similar to the corresponding training data, then it is detected as unknown. The basic operation followed on supervised classification was;

- $\quad$ fining of Training Sites: As a first step in supervised classification, training sites for each land cover classes were defined. The selection of the training sites was based on those areas clearly identified in all sources of image.

- Extraction of Signatures: After crating training samples the next step was to create statistical characterizations of each information. These are called Signatures in ArcMap 10.5. In this step signature files (gsg file) were created for every informational class. The gsg files contain a variety of information about the land cover classes described. 
After the entire signature files have been created, and then all were saved.

- Classification of the Image (Supervised classification): After defined training classes the supervised classification has been applied. In order to represent a particular class one or more than one training area was used. During the supervised classification process, the entire signature file was selected in order to be used on the classification process. Then Image was classified into five classes as water body, built up area, agriculture area, barren lands and forest over.

Accuracy assessment- The most common way to assess the accuracy of the classified image is to create a set of random points from the ground truth data and compare them through a confusion or error matrix. A confusion matrix contains information about actual and predicted classifications done by a classification system [11]. The pixel that has been categorized from the image was compared with the same site in the field for ground verification.

TABLE 1: LU/LC ClASSIFICATION

\begin{tabular}{|l|l|}
\hline $\begin{array}{l}\text { LU/LC } \\
\text { Classes }\end{array}$ & Description \\
\hline $\begin{array}{l}\text { Water } \\
\text { Bodies }\end{array}$ & Lakes, reservoirs, rivers, streams, ponds \\
\hline $\begin{array}{l}\text { Built-up } \\
\text { Area }\end{array}$ & $\begin{array}{l}\text { Buildings and manmade structures such as residential, } \\
\text { commercial, industrial areas, transportation and } \\
\text { communication, public areas. }\end{array}$ \\
\hline $\begin{array}{l}\text { Agricult } \\
\text { ure }\end{array}$ & All crop lands and home gardens \\
\hline $\begin{array}{l}\text { Barren } \\
\text { Lands }\end{array}$ & $\begin{array}{l}\text { Barren lands, play grounds, open spaces uncultivated } \\
\text { agricultural lands }\end{array}$ \\
\hline $\begin{array}{l}\text { Forest } \\
\text { cover }\end{array}$ & Dense forest, light forest, scrub lands \\
\hline
\end{tabular}

The overall accuracy is usually expressed the amount of corrected mapped sites out of all of the referenced sites. It is presented as a percentage with $100 \%$ accuracy is denoted perfect classification where all reference sites were classified correctly.

$$
\text { Overall Accuracy }=\frac{\begin{array}{c}
\text { Total number of } \\
\text { correct samples }
\end{array}}{\text { Total number of samples }} \times 100 \%
$$

Besides the overall accuracy, the classification accuracy of individual classes was calculated using the user's accuracy and the producer's accuracy. The producer's accuracy shows how often are real ground features correctly shown on the classified map. It is the map accuracy from the point of view of the mapmaker (the producer). Another way the producer's accuracy measures how well a certain area has been classified.
Producer's Accuracy

$$
\begin{gathered}
\begin{array}{c}
\text { Number of correclty } \\
\text { classified pixels in } \\
\text { each category }
\end{array} \\
\begin{array}{l}
\text { Total number of } \\
\text { referece pixels in }
\end{array} \\
\quad \text { that category } \\
\quad \text { (Colum total) }
\end{gathered}
$$

Meanwhile, the user's accuracy from the point of view of a map user. It shows how often the class on the map will accurately be present on the ground.

$$
\text { User's Accuracy }=\frac{\begin{array}{c}
\text { Number of correclty } \\
\text { classified pixels in } \\
\text { each category }
\end{array}}{\begin{array}{c}
\text { Total number of } \\
\text { referece pixels in } \\
\text { that category } \\
\text { (Row total) }
\end{array}} \times 100 \%
$$

Kappa coefficient $(\mathrm{K})$ is another measurement used for accuracy assessment. It is generated from a statistical test to evaluate the accuracy of classification. The value of Kappa can range between -1 and 1 , where 0 represents that the classification is no better than random classification. Negative values represent the classification is significantly worse. 1 represents that the classification is significantly better than random.

$K=\frac{N \sum_{i=1}^{r} x_{i i}-\sum_{i=1}^{r}\left(x_{i+} \times x_{+i}\right)}{N^{2}-\sum_{i=1}^{r}\left(x_{i i} \times x_{+i}\right)}$

Where;

$\mathrm{r} \quad=$ number of rows and columns in error matrix

$\mathrm{N}=$ total number of observations (pixels)

Xii = observation in column $\mathrm{i}$ and row $\mathrm{i}$

$\mathrm{Xi}+=$ marginal total of row $\mathrm{i}$

$\mathrm{X}+\mathrm{i}=$ marginal total of column

\section{2) NDVI Analysis}

Dense vegetation value is identified using NDVI (Normalized Difference Vegetation Index. NDVI uses band 3 (Red) and 4 (Near Infrared) for Landsat 7, and band 4 (Red) come with band 5 (Near Infrared) for Landsat 8. NDVI is approaching the calculation of greenness degree. The greenness degree of the image correlates with vegetation crown density. NDVI has a correlation with chlorophyll contain. NDVI spread in range 1 until +1 . More number of NDVI indicates more number of crown density. The normalized difference vegetation index (NDVI) is one among the foremost widely used vegetation indexes and its utility in satellite assessment and monitoring of global vegetation cover. NDVI is formulated as below: 
$N D V I=\frac{N I R-R E D}{N I R+R E D}$

Where,

NIR - Near Infrared Reflectance

RED - Red Reflectance

NDVI values vary with the absorption of red light by plant chlorophyll and the reflection of infrared radiation by waterfilled leaf cells [12]. All visible ranges are captured by the Satellite camera in form of bands through which features can be extracted after applying the NDVI method for different characteristics [13]. NDVI process to split each of the bands in a multi-spectral remote sensing satellite images, for the detection of the vegetation index. Then NDVI method is applied according to its characteristic vegetation type at different NDVI threshold values such as -1.0, 0.0 0.15, 0.3, $0.45,0.6$ and, 1.0.

\section{3) IDW method}

Inverse Distance Weighting (IDW) is one of the interpolation methods which can assess the temporal and spatial distribution of the air temperature. It is the process of using points with known values or sample points to estimate values at other unknown points. It can be used to predict unknown values using known values for any geographic point data, such as elevation, rainfall, temperature, population density, chemical concentrations, noise levels, etc.

\section{RESULTS \& DISCUSSION}

\section{A. Land use and land cover (LU/LC) classification}

Based on the satellite image classification observation of the current study area, five major land uses and land cover types were identified. These include Reservoir, Forest, Agriculture, Buildup areas, Barren Lands. The Fig. 3 shows LU/LC study for 2008 and 2019 in Hambantota Divisional Secretariat Division.

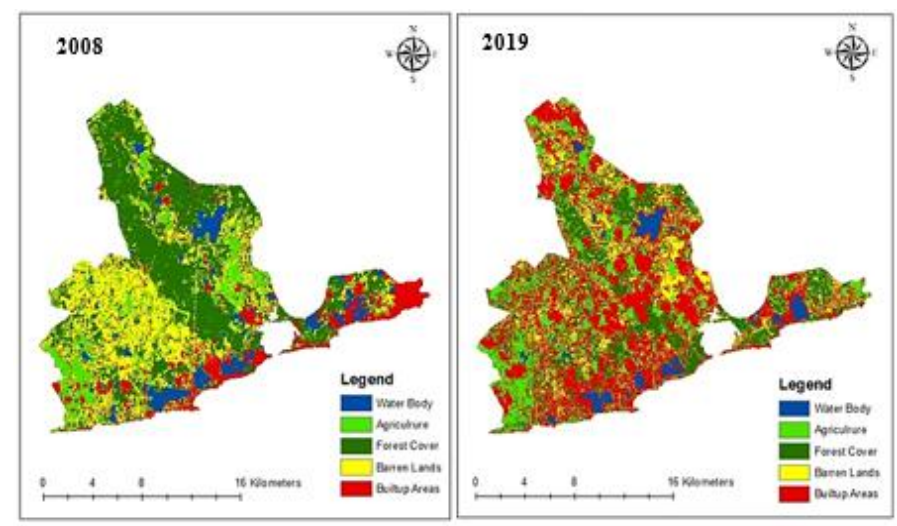

Fig. 3LU/LC map for 2008 and 2019
TABle 2: Lu/LC ClassificATION AND TheIR CORRESPONDING AREAS For 2008 AND 2019

\begin{tabular}{|c|c|c|c|c|c|}
\hline \multirow[b]{2}{*}{ Category } & \multicolumn{2}{|c|}{2008} & \multicolumn{2}{|c|}{2019} & \multirow[b]{2}{*}{$\begin{array}{c}\text { Conversion } \\
(+/-)\end{array}$} \\
\hline & $\operatorname{Area}\left(\mathrm{m}^{2}\right)$ & $\begin{array}{c}\text { Area } \\
(100 \% \\
)\end{array}$ & $\operatorname{Area}\left(\mathrm{m}^{2}\right)$ & $\begin{array}{c}\text { Area } \\
(100 \% \\
)\end{array}$ & \\
\hline $\begin{array}{l}\text { Water } \\
\text { Body }\end{array}$ & $26,398,112$ & 8.57 & $33,765,786$ & 10.96 & $+7,367,674$ \\
\hline $\begin{array}{c}\text { Agricultur } \\
\mathrm{e}\end{array}$ & $34,086,890$ & 11.06 & $35,449,544$ & 11.50 & $+1,362,654$ \\
\hline $\begin{array}{l}\text { Forest } \\
\text { Cover }\end{array}$ & $\begin{array}{c}129,283,03 \\
2 \\
\end{array}$ & 41.95 & $71,089,945$ & 23.07 & $\begin{array}{c}- \\
58,193,087 \\
\end{array}$ \\
\hline $\begin{array}{l}\text { Barren } \\
\text { Lands }\end{array}$ & $79,492,776$ & 25.80 & $43,737,864$ & 14.19 & $\begin{array}{c}- \\
35,754,912\end{array}$ \\
\hline $\begin{array}{c}\text { Buildup } \\
\text { Areas }\end{array}$ & $38,895,099$ & 12.62 & $\begin{array}{c}124,112,76 \\
3\end{array}$ & 40.28 & $\begin{array}{c}+85,717,66 \\
4\end{array}$ \\
\hline
\end{tabular}

Table 2 demonstrates the LU/LC changes between 2008 and 2019 quantitatively. According to the values given by the table, in 2008 forest cover obtained a larger area than other land use classifications. Forest area covered by $41.95 \%$, and barren land covered by $25.08 \%$ of the total land. Water body, agriculture, and build-up areas gain $8.57 \%, 11.06 \%$, and $12.62 \%$, respectively which are proven the least amount of land use categories in study area. Land use classification in 2019 indicates that forest cover occupied $23.07 \%$ and built up areas occupied $40.28 \%$ proven huge increment of buildup areas by $27.66 \%$ and decrement of forest areas by $18.88 \%$. However, the area belongs to water body gain $10.96 \%$, agriculture $11.50 \%$ showing slight increment than 2008 by $2.39 \%, 0.44 \%$, and barren lands gain $14.19 \%$ which decreased by $11.61 \%$. According to LU/LC in both years, water bodies, agriculture, and build-up areas had been increased by means of 736.8 hectares, 136.2 hectares, and 8571.8 hectares, respectively. Forest and barren lands have been reduced by 5819.3 hectares, and 3475.4 hectares, respectively.
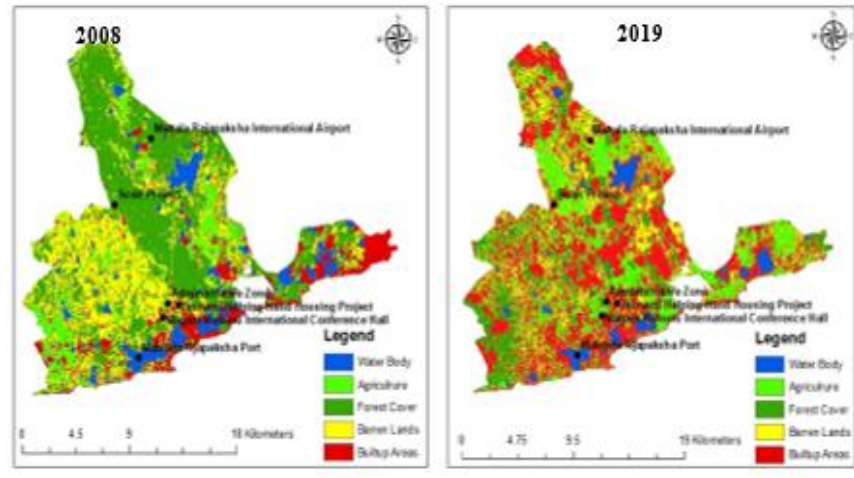

Fig. 3LU/LC changes in development projects areas

Fig. 4 clearly shows the qualitative changes of the LU/LC in the new development project areas. The change of the forest cover is highly illustrated in the images and with respect to the forest cover reduction as well as the high increment of buildup areas and slight increment of water body, agriculture and barren land reduction are clearly shown. The reason for these changes is the rapid development in the Hambanotota divisional secretariat area after 2008. In order to develop 
Hambantota district as the second largest hub in Sri Lanka, highways, Magam Ruhunu international conference hall, Mahinda Rajapaksha international port, Tsunami helping hand housing project, Mattala Rajapaksha International airport, new administrative areas, solar panel projects were introduced and those developments were carried out after 2009. After the establishment of the development programs, this area was highly affected from deforestation and urbanization which is illustrated in the fig.4.

\section{B. Accuracy Assessment}

The accuracy of the land cover classification from supervised classification was analyzed, evaluated, and presented as a confusion or error matrix table. The results of the confusion matrix for supervised classification of the years 2008 and 2019 are presented in Tables 3 and 4.

TABle 3: Confusion Matrix Of The SuPERvised Classification IMAge FOR 2008

\begin{tabular}{|c|c|c|c|c|c|c|c|}
\hline Classified & \multicolumn{7}{|c|}{ Referenced Data } \\
\hline $\begin{array}{l}\text { LU/LC } \\
\text { classes }\end{array}$ & WB & A & $\mathrm{FC}$ & $\mathrm{BL}$ & BA & $\begin{array}{l}\text { Raw } \\
\text { Total }\end{array}$ & $\begin{array}{c}\text { User Accuracy } \\
(\%)\end{array}$ \\
\hline $\begin{array}{l}\text { Water Body } \\
\text { (WB) }\end{array}$ & 6 & 0 & 0 & 0 & 0 & 6 & 100 \\
\hline $\begin{array}{l}\text { Agriculture } \\
\text { (A) }\end{array}$ & 0 & 6 & 0 & 0 & 0 & 6 & 100 \\
\hline $\begin{array}{c}\text { Forest Cover } \\
(\mathrm{FC})\end{array}$ & 0 & 0 & 6 & 0 & 0 & 6 & 100 \\
\hline $\begin{array}{l}\text { Barren Lands } \\
\text { (BL) }\end{array}$ & 0 & 0 & 1 & 5 & 0 & 6 & 83.3 \\
\hline $\begin{array}{c}\text { Built-up } \\
\text { Areas (BA) }\end{array}$ & 0 & 1 & 1 & 1 & 3 & 6 & 50 \\
\hline Column Total & 6 & 7 & 8 & 6 & 3 & 30 & Overall \\
\hline $\begin{array}{c}\text { Producer } \\
\text { Accuracy }(\%)\end{array}$ & 100 & 85.7 & 75 & 83.3 & 100 & & $\begin{array}{c}\text { Accuracy }= \\
86.7 \%\end{array}$ \\
\hline
\end{tabular}

TABLE 4: CONFUSION MATRIX OF THE SUPERVISEd ClasSIFICATION IMAGE FOR 2019

\begin{tabular}{|c|c|c|c|c|c|c|c|}
\hline Classified & \multicolumn{7}{|c|}{ Referenced Data } \\
\hline $\begin{array}{l}\mathrm{LU} / \mathrm{LC} \\
\text { classes }\end{array}$ & WB & A & $\mathrm{FC}$ & BL & BA & $\begin{array}{c}\text { Raw } \\
\text { Tota } \\
1 \\
\end{array}$ & $\begin{array}{c}\text { User } \\
\text { Accuracy } \\
(\%)\end{array}$ \\
\hline $\begin{array}{l}\text { Water Body } \\
\text { (WB) }\end{array}$ & 6 & 0 & 0 & 0 & 0 & 6 & 100 \\
\hline $\begin{array}{l}\text { Agriculture } \\
\text { (A) }\end{array}$ & 0 & 6 & 0 & 0 & 0 & 6 & 100 \\
\hline $\begin{array}{l}\text { Forest Cover } \\
\text { (FC) }\end{array}$ & 0 & 1 & 5 & 0 & 0 & 6 & 83.3 \\
\hline $\begin{array}{l}\text { Barren Lands } \\
\text { (BL) }\end{array}$ & 1 & 1 & 0 & 3 & 0 & 6 & 50 \\
\hline $\begin{array}{c}\text { Built-up } \\
\text { Areas (BA) }\end{array}$ & 0 & 0 & 1 & 0 & 5 & 6 & 83.3 \\
\hline Column Total & 7 & 8 & 6 & 3 & 5 & 30 & Overall \\
\hline $\begin{array}{c}\text { Producer } \\
\text { Accuracy }(\%)\end{array}$ & 85.7 & 75 & 83.3 & 75 & 100 & & $\begin{array}{l}\text { Accuracy } \\
=83.3 \%\end{array}$ \\
\hline
\end{tabular}

TABle 5: COMPARISON OF THE OVERALl ACCURACy AND KaPPA StatistiC

\begin{tabular}{|c|c|c|}
\hline Year & $\begin{array}{c}\text { Overall Accuracy } \\
(\%)\end{array}$ & Kappa Coefficient \\
\hline 2008 & 86.7 & 0.888 \\
\hline 2019 & 83.3 & 0.912 \\
\hline
\end{tabular}

When considering the accuracy assessment of the LU/LC classification, in 2008 the overall accuracy is obtained as $86.7 \%$. The user accuracy for water bodies, agriculture, and forest cover is obtained as $100 \%$ and for barren lands and built-up areas are recorded as $83.3 \%$ and $50 \%$ respectively. Producer accuracy for water bodies and barren land recorded as $100 \%$, and agriculture, forest cover, and barren lands, obtained $85.7 \%, 75 \%$, and $83.3 \%$ respectively. According to Table 5, the Kappa Index Accuracy is recorded as 0.888 which proves a complete agreement between classified maps and the reference data.

Compared 2008, in 2019, the overall accuracy is recorded as $83.3 \%$. The user accuracy for water bodies and agriculture is $100 \%$, forest cover and built up areas is $83.3 \%$ and barren land is $50 \%$. The producer accuracy, $100 \%$ for barren lands, $85.7 \%$ for water body, $75 \%$ for agriculture, and barren lands and $83.3 \%$ for forest cover. The Kappa Index Accuracy is obtained 0.912 .

\section{NDVI analysis}

In 2008, the study found NDVI range from 1 to -0.652893 . It increases range from 1 to -1 in 2019. Base on categorization, NDVI is divided into 6 classes as non-vegetation, lowest dense, lower dense, moderately dense, dense, and highest dense as shown in Table 6.

When considering the NDVI maps for 2008 and 2019 with the major developments, it clearly shows the reduction of the NDVI values in certain places. The changes of the NDVI values can qualitatively describe using Fig. 5. Hence values 1 represents the green color it gives the indication of healthy vegetation cover, as well as the value -1 represent the red color gives the indication of unhealthy vegetation cover. However the yellow represent the intermediate value that is given by the middle value. When comparing two maps the location of the international airport represent yellow color than 2008 that indicated the reduction of vegetation cover due to the developments. This is the same for the location of a solar project, administrative areas, port, housing project, and conference hall also.

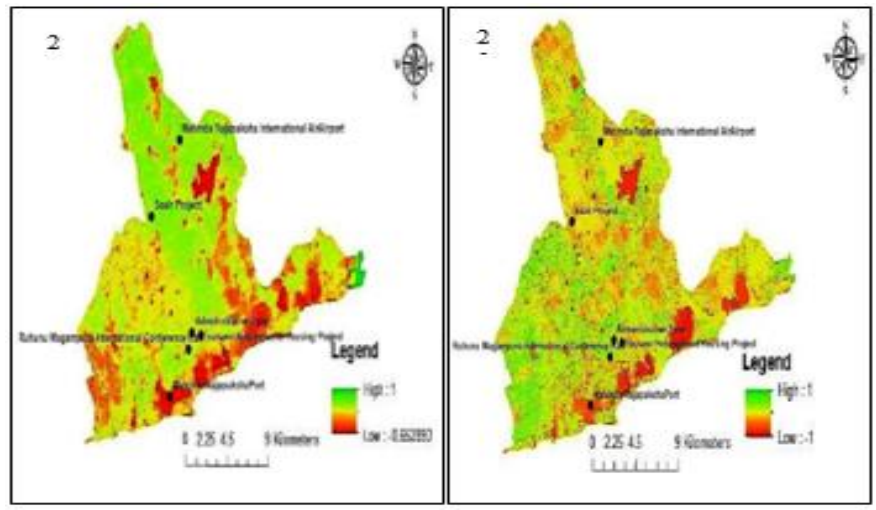

Fig. 4 NDVI Analysis for 2008 and 2019 
TABle 6: InCREASEd AND DeCREASEd The LEVEl Of VegETATION DENSITY

\begin{tabular}{|c|c|c|c|c|c|c|c|}
\hline \multirow{2}{*}{ Dense Class } & \multirow{2}{*}{ NDVI } & \multicolumn{2}{|c|}{2008} & \multicolumn{2}{|c|}{2019} & \multicolumn{2}{|c|}{ Changed $\left(\mathrm{m}^{2}\right)$} \\
\hline & & Area $\left(\mathrm{m}^{2}\right)$ & $\%$ & Area $\left(\mathrm{m}^{2}\right)$ & $\%$ & Increased & Decreased \\
\hline $\begin{array}{c}\text { Non } \\
\text { Vegetation }\end{array}$ & $<0$ & 38,910 & 0.01 & 285,076 & 0.09 & 246,166 & - \\
\hline Lowest Dense & $0-0.15$ & $17,825,789$ & 5.48 & $24,528,851$ & 7.47 & $6,703,062$ & - \\
\hline Lower Dense & $\begin{array}{l}0.15- \\
0.30\end{array}$ & $5,816,660$ & 1.79 & $53,447,300$ & 16.28 & $47,630,640$ & - \\
\hline Dense & $\begin{array}{c}0.30- \\
0.45\end{array}$ & $153,454,262$ & 47.17 & $139,803,279$ & 42.58 & - & $13,650,983$ \\
\hline Higher Dense & $\begin{array}{c}0.45- \\
0.60\end{array}$ & $107,585,598$ & 33.07 & $91,231,218$ & 27.79 & - & $16,354,380$ \\
\hline \multirow[t]{2}{*}{ Highest Dense } & $>0.60$ & $40,603,436$ & 12.48 & $19,027,931$ & 5.80 & - & $21,575,505$ \\
\hline & Total & $325,324,655$ & 100.00 & $328,323,655$ & 100 & & \\
\hline
\end{tabular}

Table 6 shows quantitative increased and decreased levels of vegetation density in Hambantota DS Division between 2008 and 2019. Normally the study area is flat and the main vegetation is paddy lands and barren lands. Meanwhile, some forest cover is found in part of the study area. When considering the NDVI classification in the 2008, the area has the highest dense which reflects more vegetation cover (12.48\%) than in 2019. In 2019 higher dense loss about $21,575,505 \mathrm{~m}^{2}$. It indicates forest and vegetated areas have been degraded or converted into other land use. In 2019, it is reduced up to $5.80 \%$. Non-vegetation class is increased in 2019 as 0.09 than 2008 value that shows the huge reduction of vegetation cover in the study area. This is happened due to changes in the land use and land cover with the developments in Hambantota district from formal and informal authorities. With urbanization, human converts forests to agricultural land that triggering land-use changes.

\section{Spatial Distribution of Air Temperature}

Air temperature is taken into consider as an essential parameter that impacts the entire weather changes of a place. Speed urbanization and deforestation are the predominant sources to change the air temperature in a particular area.

Fig. 6 shows the spatial distribution of annual air temperature in Hambantota divisional secretary division. Spatially there are some variations that can be seen in the distribution of annual air temperature in Hambantota district for 2008 and 2019. In 2008, the maximum annual air temperature range was recorded as $26.21-26.32$ degrees Celsius and that was obtained in Badagiriya tank, Bundala Lewaya, and Mirijjawila stations, and minimum annual air temperature range 25.76 25.87 degrees Celsius was obtained in the Mahalewaya station. In 2019 maximum annual air temperature range was recorded as 27.02 - 27.14 degrees Celsius and that was obtained in the same stations and the minimum annual air temperature range of 26.53- 26.65 degrees Celsius was obtained in the Mahalewaya station also. The maximum and the minimum annual air temperature values are increased in 2019 than 2008. The reasons for this increment are the influence of rapid deforestation and urbanization. The distribution of the high-temperature variation in above- mentioned areas has occurred with the reduction of the forest cover in Hambantota district with of development projects that introduced with the changes of the government authorities after 2008 .

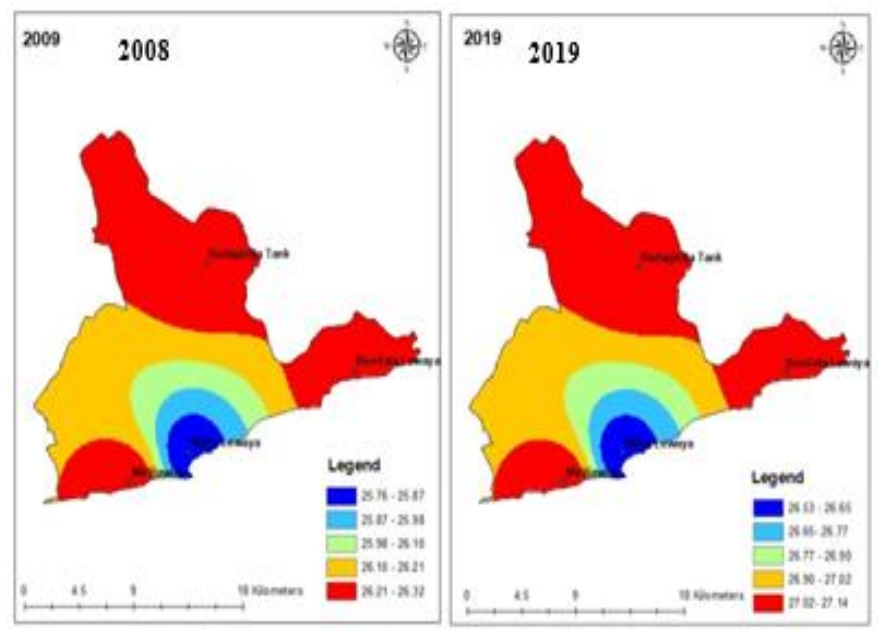

Fig. 5 Spatial distribution of annual air temperature for 2008 and 2019

\section{E. Seasonal Distribution of the Temperature}

When considering the monthly average air temperature data for 2008 and 2019 there are few variations recognized in the Hambantota divisional secretariat division. In 2008 and 2019 the study area experienced high temperatures during the First Inter Monsoon Season especially in March to April due to the angle of the sun being directly overhead to the Hambantota district. During this period the maximum air temperature values are 26.32 and 27.14 degrees Celsius respectively.

The minimum average temperature in the study area, in 2008 and 2019 that was obtained in the period of North West inter monsoon period, especially in December- January as 24.96 and 25.45 degrees Celsius respectively due to influence of the dry and cold wind blowing from the Indian land-mass. Because the position of the sun's angle is almost at ninety degrees to Sri Lanka during March-April, the hottest month of the Hambanota district is March in which the average maximum air temperature amounts to 28.5 degrees Celsius. 
The coldest month is January, with an average temperature of 25.37 degrees Celsius. Fig. 7 shows the trend of annual air temperature in Hambantota Divisional Secretariat Division. The trend line gives the relationship of annual air temperature variation between 2008 to 2019 .

Fig. 7 shows the trend of annual air temperature in Hambantota Divisional Secretariat Division. The trend line gives the relationship of annual air temperature variation between 2008 to 2019. The correlation coefficient also provides necessary evidence for appropriates of the curve fitted as shown in Table 7.

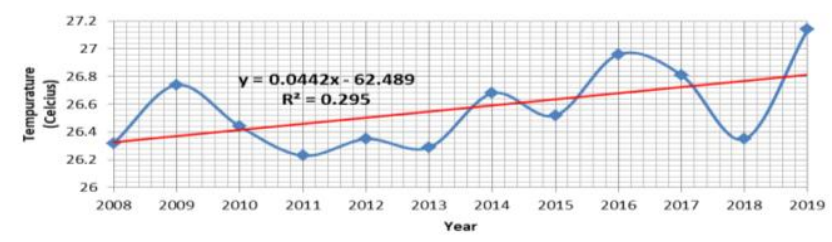

Fig. 6The trend of annual air temperature in Hambantota Divisional Secretariat Division between 2008 to 2019

Although between 2010 to 2013 the air temperature values decrease after 2013 again those values are increased. Based on the regression line, the average air temperature for 2030 at Hambantota divisional secretariat division is 27.24 degrees Celsius.

TABLE 7: REgRESSION PARAMETERS For STATIONS IN HAMBANTOTA DIVISIONAL SECRETARIAT DIVISION

\begin{tabular}{|c|c|c|c|c|}
\hline Station & $\begin{array}{c}\text { Equation of the } \\
\text { Trend Line }\end{array}$ & Intercept & Slope & $\mathrm{R}^{2}$ \\
\hline Locations & & & \\
$\begin{array}{c}\text { Badagiriya tank } \\
\text { Bundala Lewaya } \\
\text { Mirijjawila }\end{array}$ & $\mathrm{y}=0.0442 \mathrm{x}-62.489$ & 26.53 & 0.0442 & 0.295 \\
\hline
\end{tabular}

\section{CONCLUSION}

The LU/LC change in Hambantota Divisional Secretariat Division (DSD) show significant changes after 2009 due to the vast development programs which were carried out by the government authority. This study is focused to evaluate and study the spatial and temporal variation of land use/land cover changes and impact on climate in Hambantota DSD from 2008 to 2019. This study revealed significant changes of the LU/LC changes during the past 11 years proved that built-up areas have been increased significantly and forest cover and barren lands have been lost significantly during this period. There is a slight increment shown in the water body and agricultural areas as well. This concludes a certain amount of land-use has been converted to another land use class and land cover got changed timely, with deforestation and urbanization and therefore most of the development programs are not considered as sustainable. Therefore those developments programs are considered as the main reason to change the significant change of LU/LC changes in the Hambantota DSD.
When considering the NDVI values that approaching the calculation of greenness degree, the healthy vegetation index is reduced in 2019 at the locations which are used for implementing such development activities. This gives the indication of vegetation removal or land-use change in those selected areas.

The study of spatial and temporal variation of temperature for Hambantota DSD shows significant spatial changes of air temperature have taken place within last the 11 years. The maximum annual air temperature has been increased in 2019 than 2008. The trend analysis shows the increment of maximum annual temperature in 2030 also.

This study shows the relationship between changes in air temperature and the LU/LC changes. The reduction of vegetation cover due to vast urbanization and deforestation during last 11 years is the major reason for the increment of air temperature of the Hambantota DSD. It caused to change the climate of the area. Climate change and urbanization are two major ongoing processes worldwide and in past few years their impact on ground started becoming visible [14]. The combined impacts of urbanization and climate change will potentially have large impacts on future urban temperatures, and exacerbate existing heat stress [15], particularly in developing countries like Sri Lanka. In addition, Hambantota is considered as a dry zone, the rapid urbanization without good environmental protection plans result to deforestation and this will disturb to normal process of evaporation, transportation activities. It will cause to further temperature increment and eventually result the Urban Heat Island (UHI) effects. The impacts of urbanization and climate change are revealed as change of annual rainfall, urban warming, extreme weather events, and urban health hazards [16] also.

Recommendations are aware of urban planners, decisionmakers, administrative officers to consider the land-use changes and the effects of land degradations and deforestation. Hence results revealed a huge reduction of forest cover over the years, future construction activities and decisions should be taken in order to reduce further land degradation and deforestation, as well as necessary actions, should be taken to increase the forest cover by introducing "tree-planting programs" by local government authorities and other responsible organizations. Urban planners should designed sustainable urbanization plans with resilient habitat for existing populations considering social, economic, environmental impact, without compromising the same experience for the future generations.

\section{REFERENCES}

[1] R J M Uduporuwa.(2020). Spatial and Temporal Dynamics of Land Use/Land Cover in Kandy City, Sri Lanka: An Analytical Invastigation with Geospatial Techniques. Ameriican Scientific Research Journal for Engineering, Technology, and Sciences, 149166.

[2] I H Mohd, Z H Pakhriazad, F M Shahrin. (2009). Evaluating Supervised and Unsupervsed Techniques for Land Cover Mapping 
Using Remote Sensing Data. Malayasian Journal of Society and Space, $1-10$.

[3] Ayyanna, B.S. Polisgowdar, M.S. Ayyanagowdar, Anilkumar T. Dandekar, G.S. Yadahalli and M.A. Bellakki. (2018). Accuracy Assessment of Supervised and Unsupervised Classification Using Landsat-8-Imagery of D-7 Shahapur Branch Canal of UKP Command Area Karnataka, India. International Journal of Current Microbiology and Applied Sciences, 205-216.

[4] R Vimala et. al. (2020). Unsupervised ISODATA algorithm classification used in the landsat image for predicting the expansion of Salem urban, Tamil Nadu. Indian Jouranal of Science and Technology, 1619-1629.

[5] A Zaitunah,Samsuri, A G Ahamd and R A Safitri. (2018). Normalized difference vegetation index (ndvi) analysis for land covertypes using landsat 8 oli in besitang watershed, Indonesia. IOP Conference Series: Earth and Environmental Science.

[6] P Nathalie et.al. (2011). The Normalized Difference Vegetation Index(NDVI): unforeseen successes in animal ecology. CLIMATE RESEARCH, 15-27.

[7] D M El-Shikha a, P Waller, D Hunsaker, T Clarke, E Barnes. (2007). Ground-based remote sensing for assessing water andnitrogen status of broccoli. Agricultural Water Management, 183-193.

[8] N Alahacoon and M Edirisinghe.(2021). Spatial Variability of Rainfall Trends in Sri Lanka from 1989 to2019 as an Indication of Climate Change. International Journal of Geo Infromation.

[9] B Sandra, J Kossin and S Donner.(2014). The Impact of Climate Change. In A. S. Zommers, Reducing Disaster: Early Warning Systems For Climate Change (pp. 21-49).

[10] S R Sophia, J M Ndambuki.(2017). Accuracy Assessment of Land Use/Land CoverClassification Using Remote Sensing and GIS Internationa Journal of Geo Sciences, 611-622.

[11] M Kamel, M Youssef, M Hassan, F Bagash.(2016). Utilization of ETM+ Landsat data in geologic mapping of wadi Ghadir-Gabal Zabara area,Central Eastern Desert, Egypt. The Egyptian Journal of Remote Sensing and Space Sciences, 343-360.

[12] G G Meera, S Parthiban, N Thummalu, A Christy. (2012). Ndvi: Vegetation change detection using remote sensingand gis - A case study of Vellore District. 3rd International Conference on Recent
Trends in Computing 2015 (ICRTC-2015) (pp. 1199-1210). Procedia Computer Science.

[13] A. K. Bhandaria, A Kumara, and G K Singh. (2012). Feature Extraction using Normalized Difference VegetationIndex (NDVI): a Case Study of Jabalpur City. 2nd International Conference on Communication, Computing \& Security [ICCCS-2012] (pp. 612621). Procedia Technology.

[14] V. Rangari et.al (2021). Flood-hazard risk classification and mapping for urban catchment under different climate change scenarios: A case study of Hyderabad city. The Journal of Urban Climate,Vol. 36, pp 100793.

[15] C.B. Field et.al (2014). Climate Change 2014: Impacts, Adaptation, and Vulnerability. Part A: Global and Sectoral Aspects. Contribution of Working Group II to the Fifth Assessment Report of the Intergovernmental Panel on Climate Change. Cambridge, UK and New York, USA: Cambridge University Press. pp. 1-32.

[16] M. De Zoysa (2020). Urbanization, Climate Change and Environmental Resilience: Experiences in Sri Lanka. Urban studies and public administration, Vol. 4, No. 1(pp. 46-84).

[17] IPCC (2014) Climate change 2014: impacts, adaptation, and vulnerability. Part A: global and sectoral aspects. Contri-bution of working group II to the fifth assessment report of the intergovernmental panel on climate change [Field,C.B., V.R. Barros, D.J. Dokken, K.J. Mach, M.D. Mas-trandrea, T.E. Bilir, M. Chatterjee, K.L. Ebi, Y.O. Estrada,R.C. Genova, B. Girma, E.S. Kissel, A.N. Levy, S. Mac-Cracken, P.R. Mastrandrea, and L.L. White (eds.)]. Cam-bridge University Press, Cambridge, United Kingdom and New York, NY, USA

[18] IPCC (2014) Climate change 2014: impacts, adaptation, and vulnerability. Part A: global and sectoral aspects. Contri-bution of working group II to the fifth assessment report of the intergovernmental panel on climate change [Field, C.B., V.R. Barros, D.J. Dokken, K.J. Mach, M.D. Mas-trandrea, T.E. Bilir, M. Chatterjee, K.L. Ebi, Y.O. Estrada, R.C. Genova, B. Girma, E.S. Kissel, A.N. Levy, S. Mac-Cracken, P.R. Mastrandrea, and L.L. White (eds.)]. Cam-bridge University Press, Cambridge, United Kingdom and New York, NY, USA 